\title{
Community Participation in the Development of Secondary Schools in Plateau State Nigeria
}

\author{
Theresa Stephen Gyang ${ }^{1}$, Joshua Musa Gusen ${ }^{2}$ \\ ${ }^{1}$ Department of Educational Foundations, Faculty of Education, University of Jos, Jos, Nigeria \\ ${ }^{2}$ Ministry of Education, Jos, Nigeria
}

Email address:

tessysgyang@yahoo.com (T. S. Gyang), gusenjoshua2019@gmail.com (J. M. Gusen)

\section{To cite this article:}

Theresa Stephen Gyang, Joshua Musa Gusen. Community Participation in the Development of Secondary Schools in Plateau State Nigeria. International Journal of Secondary Education. Vol. 9, No. 3, 2021, pp. 86-90. doi: 10.11648/j.ijsedu.20210903.12

Received: June 28, 2021; Accepted: July 14, 2021; Published: August 4, 2021

\begin{abstract}
The paper examined community participation in the development of secondary schools in Plateau State. Education being a capital intensive investment is faced with numerous challenges that government alone cannot handle. Many secondary schools in Plateau state are operating with scarce resources resulting to low standard output. This requires the participation of stakeholders to the development of the schools. The roles of community and other stakeholders in contributing to the development of secondary schools seem to be haphazardly done due to poor advocate and ignorance to some extent. Many schools are faced with inadequate infrastructure, inadequate funds and poor instructional materials as well as inadequate teaching staff. The paper recommends among others the need for sensitization and mobilization of the public to participate fully in the development of secondary schools, involve the immediate communities in decision making of the schools to facilitate their contributions for the development of secondary schools in Plateau State, and regular workshops, seminars and conferences should be organized for teachers to establish cordial relationships with their immediate communities for adequate participation in school activities.
\end{abstract}

Keywords: Community, Development, Secondary School, Plateau State, Nigeria

\section{Introduction}

Education is a veritable instrument for achieving economic development and social transformation of every society. It is a huge investment that is capital intensive. Considering that Education is an expensive social service, the government has taken the responsibility of financing it, and also welcomes and encourages the participation of the local communities, individuals and other organizations not only that, but has acknowledged the fact that government alone cannot fund education adequately. Hence, any country that fails to provide Education to its citizens is undermining the country's development. The Educational goals of Nigeria as stated in the National Policy on Education by the Federal Government of Nigeria [5]. The achievement of education goal is based on the acquisition of appropriate skills, the development of mental, physical, social abilities and competences so as to enable the individual contribute to the development of the community.

As laudable as the above National objectives are, the situation in Plateau State calls for a lot of concern as there are many children that are out of school. It is estimated that 10.5 million children out of the 38 million out of school children in the world are found in Nigeria [15]. No nation ever develops when majority of her youths are out of school. Plateau State is faced with many challenges confronting its Education sector. Some of the challenges are attributed to inadequate funding, shortage of manpower, inadequate supply of Educational facilities and needed equipment for effective teaching/learning process such as classrooms, furniture and laboratories among others. The result of this is poor performances of the students in both internal and external examinations conducted by WAEC and NECO [10]. Community involvement in decision making should be seen as a major yardstick to facilitate great participation of community members in school activities [4]. This could be facilitated by sensitization campaigns to the general public and influence advocacy on the need to contribute for education in Nigeria. 


\section{The Concept of Community Participation in Education}

Many authors have defined community participation from their own perspectives. Community participation is the active involvement of parents, families and local communities in the planning, designing, coordinating, executing, supervising, monitoring and evaluation of programmes or projects for better Education delivery [14]. The need for community participation in Education in Plateau State arose as a result of the myriad of challenges facing the Education sector, such as the challenge of insufficient funding. For example, the 2017 Federal Government budget for Education failed to meet the United Nations Educational, Scientific and Cultural Organization, twenty six percent (26\%) annual benchmark on Education funding. The 2017 Federal Government budget proposed the sum of $\$ 448$ billion allocated to the Education sector, thus representing about $6 \%$ of the $\$ 7.30$ trillion. This is contrary to the twenty-six $(26 \%)$ as recommended by UNESCO [11]. Poor funding results to students experiencing shortages of classrooms, furniture, books, laboratories and also teachers. Meaningful development will take place in schools only if the facilities are supplied, as their supply will enhance learning in no small measure. In community participation, the school needs are determined and appropriately tackled by the communities concerned such as parents, traditional leaders, community development leaders as well as religious leaders. This is because the development of the schools cannot be left to the government alone to handle. It requires partnership between the communities, other non-governmental organizations and the Government.

\subsection{The Concept of Secondary School Development}

In Nigeria, the community is known for its participation in the development of Education. Community participation in the development of Education in Nigeria started as far back as 1843 with the establishment of the first formal school in Badagry [2]. Since then, more communities have joined in the establishment of secondary schools across the country. In Plateau State, the community has equally joined in the establishment of community secondary schools which abound in many communities in the state. The various communities also employ and pay the teachers, they provide instructional materials to the schools such as furniture, books, chalk, laboratory equipment and also sporting facilities. The communities in liaison with other bodies such as Old Students Associations and the PTAs do donate trophies for sports, debates and quiz.

This is in addition to the offering of scholarship to deserving students from poor background to study. The aims have been to compliment the efforts of the government and also assist the existing schools established by the government. The community leaders usually sensitize the community members in enrolling their children in school. In Plateau State, there were many community secondary schools established by the various communities but now taken over by the state government. As laudable as the efforts of the communities are, the schools are now left in a dilapidated state of affairs as they lack teachers, furniture, instructional materials, classrooms and laboratories.

\subsection{The Roles of Stakeholders in the Development of Secondary Schools in Plateau State}

There are many roles played by stakeholders in the development of secondary schools in Plateau State. Some of these stakeholders are: Community Development Associations, Old Students Associations, the Parents Teachers Association and other non-governmental organizations such as Rotary Club, and UNESCO amongst others. Their roles are explained below.

(1) The Roles of Community Development Associations

Community Development Associations. This is the Confederation of Mutual Associations formed by individuals from a particular rural community but resident in different towns in the country and at times outside it. They perform the following functions:

Members of the community may contribute in terms of levies or taxes for project execution. The executive committee of the Association may tax the community members to contribute for the erection of classroom blocks, purchase of land or renovation of the entire school building. The community may set aside a day for communal work in the school.

It may launch an appeal fund or stage a cultural display to raise funds for project execution, where prominent sons and daughters from within and outside the community could be invited. It could even support in the area of materials and equipment in place of cash for project execution such as donation of cement, block and zinc.

In Plateau State, the communities have established community secondary schools which abound in many parts of the state. Some have been taken over by the state government. Not only that, the communities recruit teachers to teach in the community secondary schools, they pay the salaries of the teachers, and also embark on any work that may assist in the development of secondary schools.

(2) The Roles of Old Students Association

Old Students' Associations are organizations re-uniting former students of a college or university and can be found in many Educational institutions around the world. This body is playing useful role in the development of secondary schools in Plateau State. Some of their functions are: maintaining the ethical and moral standards of its alma mater - this is done by forming an alliance with the teaching staff to maintain high Educational standard through the provision of infrastructural as well as instructional materials. It also partners with management to meet the general needs of the schools. Not only that, they participate in meaningful ventures that will positively contribute towards national development. They also develop and maintain business contact with a view to creating job opportunities for members.

(3) The Roles of School Based Management Committees 
School Based Management Committee is the decentralization of authority from the central government to the school level. It is a form of decentralization that identifies the individual school as the primary unit of improvement and relies on the redistribution of decision through which improvement might be stimulated and sustained [8].

According to the Basic Information Handbook on School Based Management Committee, such roles amongst others are: Collaborating with the Parent Teachers' Association (PTA) in the sensitization and mobilization of parents on enrolment, attendance and retention of their children or wards in schools [9]. They monitor staff with regards to attendance of the school and effectiveness in curriculum delivery. They support school development planning, budgeting and utilization of resources in schools, as they also serve as medium of transmission of skills, knowledge, values and traditions of the community, by also assisting in the procurement of teaching/learning materials and resources. As important as the School Based Management Committee is, not many secondary schools in Plateau State have it. The lack of it poses a serious threat to the Educational development of the state. These ideas collaborate the principles of the Community-Based Education Leadership (CBEL) model developed by Gyang in the year 2020 which has four segments namely; school leadership, community leadership, collaborative leadership and the centre stage is teaching, learning and student, and school outcomes. This operates in a cycle through school-community relationships with the guidance of the school leader [6]. Therefore, the earlier all schools have it, the better for the educational development of the state.

\section{(4) The Parent Teachers Association (PTA)}

Parent Teachers Association is an amalgamation of parents of students and all the teachers of that institution. The aim has been to create a common forum where and when parents of students and their teachers meet to interact and brainstorm together on issues of common interest [13].

It brings about collective responsibilities between the schools, the teachers and parents. It fosters effective management of school facilities and also supports the schools in the provision of learning facilities, aimed at promoting quality education and increase enrolment rate. The Parent Teachers Association promotes public and private participation of parents and teachers towards the Education of their children. In Plateau State the PTA recruit teachers that teach in most of her public secondary schools. They also pay the salaries of the teachers they have employed, thus complementing the efforts of the Plateau State government in addressing the acute shortage of teachers in her public secondary schools.

The PTA also embarks on other meaningful ventures such as the provision of boreholes, classrooms, furniture, computers, sporting facilities and laboratory facilities. Not only that, they assist the various schools in organizing end of year speech and prize giving ceremonies. In fact, the PTA remains the backbone of most secondary schools in Plateau State, this they do by complimenting the efforts of the school management in the sensitization of parents on the need for them to enroll their children in school. They also ensure moral standards and academic excellence in consultation with the School Board of Management. A lot of sensitization of parents is still needed, to enable them participate fully in the Educational development of their children.

(5) Other Non-Governmental Organizations

There are non-governmental organizations rendering assistance to the various communities in Plateau State in the area of secondary school development. Some of these organizations are: Rotary Club, UNESCO, UNICEF, United States Agency for International Development (USAID), German International Development Cooperation and Japan International Cooperation Agency (JICA).

They disseminate information on current educational research through publication of books or research journals. They also sponsor research in Educational matters. They assist in the funding of Education most especially secondary schools in sub-Sahara Africa. Some of the non-governmental organizations organize seminars, workshops and conferences on Education. They promote gender equality in Education by ensuring that all sexes have equal representation in Educational enrolment. Not only that, teacher Education is promoted through funding teacher training institutions, for example, Colleges of Education or Universities. However, a lot still needs to be done in this regard, as many Educational institutions are yet to feel their impact.

\subsection{The Challenges of Developing Secondary Schools}

In spite of all these laudable efforts by the various communities and also non-governmental organizations, there are many challenges the community still face in their attempt to develop secondary school Education in Plateau State. Some of these challenges are summed up as follows:

\subsubsection{Insufficient Funding}

Insufficient funding has been a major challenge in the development of education most especially secondary education in Nigeria and Plateau State in particular. The inadequate funding has resulted into shortages of manpower, inadequate supply of educational facilities and needed equipment for effective teaching/learning process such as classes, books, furniture and laboratories among others. The result of this is poor performance of the students in both internal and external examinations such as National Examination Council (NECO) and West African Senior Secondary School Certificate Examination (WASSCE) across Plateau State. The poor funding has affected the whole country. The Federal Government budget for education has failed to meet the United Nations Educational Scientific and Cultural Organization twenty-six percent (26\%) annual budget benchmark on educational funding. The 2017 federal government budget proposed the sum of $\$ 448$ billion allocated to the education sector thus representing only about $6 \%$ of the $\$ 7.30$ trillion. This is therefore contrary to the twenty six (26\%) as recommended by UNESCO [11].

Statistics of Central Bank of Nigeria in 2010 revealed that 
between 2000 and 2010 allocation to the education sector by the federal government of Nigeria was not more than $14 \%$ of the annual budget, which was even low when compared to the allocation of countries such as Kenya, Malawi, Botswana, Angola, Sierra Leone and South Africa all in Sub-Saharan Africa. Adequate funding will increase accessibility to secondary school. No nation ever develops when its education sector is neglected.

To worsen the matter, most of the community secondary schools now taken over by the Plateau State government are in a dilapidated state of affairs. As a result of this, they are now left to the various communities to maintain. This is seen as an additional burden to the various communities. Without adequate funding, standards of education at any level shall be tantamount to a mirage, that is building castles in the air, for money is important in a school because it is used to construct buildings, purchase needed equipment, pay staff salaries and allowances, maintain the plants and also keep services going.

\subsubsection{Inadequate Manpower}

In fact, this is a major problem affecting the development of secondary schools in Plateau State (Both community and public). The shortage of teachers is adversely affecting the performance of the students in both internal and external examinations. There are many teachers teaching in the public secondary schools that are employed by the (PTA). To worsen the matter, some of them do not possess the minimum teaching qualification of the NCE. No educational system, can rise above the quality of the teachers. Shortage of teachers results to easy withdrawal of students from school. The withdrawn students easily take to some social vices such as drug addiction, kidnapping, cultism and prostitution. Even where there are teachers, they are poorly paid, thus contributing to dampening their morale. The teachers employed by the PTAs are poorly paid. The teachers therefore see their work as a stop-gap to something better in the future.

\subsubsection{Socio-economic Factor}

Parents are not left out in the blame for low enrolment of their children in school. Some parents prefer their children to help them with work on the farm, most especially during the rainy season where attendance in school is usually low, some parents prefer their children to marry easily in life so as not to be spoilt, and also for the dowry that will be gotten. The poor attendance is also caused by poor nutrition. Many families are living below the poverty line especially in subSaharan Africa for which Nigeria is a part. Many children in Plateau State are affected by some of these problems. Some of the children could therefore be found in streets trading instead of attending school. Another major problem is that of local tin mining, that has attracted a lot of school children.

\subsubsection{Inadequate and Decay Infrastructure}

School facilities are the material resources that facilitate effective teaching and learning in schools. They are things which enable a skillful teacher to achieve a level of instructional effectiveness that exceeds what is possible when they are not provided [7]. As important as they are in facilitating learning, they are in short supply in most secondary schools in Plateau State. Their shortages are affecting learning thus affecting the performances of the students in both internal and external examinations. A visit to most of the secondary schools revealed the shortages of classes, furniture, books, library and laboratory facilities. Their shortages also reduce the attendance of students to school.

\subsubsection{Communal Clashes}

Accessibility to secondary school is hindered by natural phenomena such as flood, rainstorm, fire outbreaks and also thunder and lightning. When these natural phenomena occur, they destroy schools thereby leading to the closure of the schools [3]. Floods and rainstorms are occurrences in Plateau State most especially in the southern parts. Again, communal clashes over ownership of farmlands have hindered accessibility of students to school. Another is farmers'/herders' clashes. The clashes have been a reoccurring phenomenon among communities in Plateau State. The worst hit areas have been in Jos South, Bassa, Riyom, Barkin-Ladi and Bokkos local governments. The crises have led to hundreds loss of lives. In addition are the destruction of schools and other properties. The resultant effects have been the closure of schools. Examinations for some of the affected students have been re-scheduled.

The communities in such areas have been at the receiving end. The reconstruction of the affected schools will create a lot of financial burden to the communities. This is also coupled with the fact that some of the communities are poor. The costs of building materials are rising daily. Some of the affected students will be thrown out of school and most of them will be engaged in some social vices such as drug addiction, prostitution, kidnapping, armed robbery and cultism. Many affected persons are to be found in the internally displaced persons' camps which abound in some parts of Northern and Central Plateau. Jos South alone has witnessed series of violent conflicts that have forced many residents to flee their homes to other locations for safety [12]. The conflicts have gone a long way in affecting the production of food to feed the families and sponsor the children to school. No nation can survive on hunger.

\section{Conclusion}

The development of societies rests on the importance such societies attach to Education. In the light of this, every effort should be put in place to ensure the development of Plateau State through the development of her secondary schools. Therefore, the challenges bedeviling the sector such as shortages of classes, teachers, furniture, laboratory facilities, and insecurity amongst others should be tackled.

This will in turn result in increased enrolment of children into secondary schools. The quality of instruction will also improve, thereby leading to the production of high manpower that will in turn serve the state and the country as a whole. 


\section{Recommendations}

Education is key to the development of any Nation. Therefore, for Nigeria to make any meaningful progress in her development, priority attention should be given to the development of the Education sector. In Plateau State, there are many challenges bedeviling the sector such as poor funding, poor infrastructure as well as shortage of learning facilities amongst others. When these challenges are tackled, the better will it be for the overall development of the State and the nation as a whole.

In view of the above challenges, the following recommendations are made:

1) There should be increased funding of the education sector by both the government and the community.

2) More learning facilities should be supplied to the schools by both the government and the community. Such facilities include classes, books, furniture and laboratory equipment.

3) More teachers should be employed by both the government and the community in order to address the acute shortage of teachers being experienced in our secondary schools.

4) Government should organize regular workshops, seminars and conferences for teachers and principals with a view to updating their knowledge on recent developments in their fields of specialization, to also create cordial relationships with their immediate communities to facilitate participation in school activities.

5) School Administrators should ensure adequate sensitization of parents and community leaders towards ensuring that they send their children to school.

6) Communal clashes/insurgency should be addressed adequately by the government with a view to ensuring that the communities have safety of their lives. Through that, they will be encouraged to enroll their children in school.

7) Government to set modalities that will enforce secondary school administrators to involve their immediate communities in decision making on school matters.

\section{References}

[1] Banka, Scholastic, Bua and Terhile (2015). Impact of old students association on the management of secondary schools in Z one B Senatorial District of Benue State. Journal of Innovative Education Research, 3 (1), 35-45.
[2] Barsha, T. (2015). The impact of community participation on the management of public primary school in the local government area of Kaduna state. An unpublished M. Ed. dissertation, Ahmadu Bello University Zaria.

[3] Brooking, B. (2008). Internally displaced people. Human rights and natural disasters operational guidelines and field manual on the human rights protection in situations of natural disaster, Washington DC: United Nations.

[4] Ede, A. S. (2000). Educational administration and Management. Jos: Ichejum Publications.

[5] Federal Republic of Nigeria (2013). The national policy on education. Yaba, Lagos: NERDC Press.

[6] Gyang, T. S. (2020). Educational Leadership Response to the COVID-19 Pandemic Crisis in Nigeria. International Studies in Educational Administration, Journal of the Commonwealth Council for Educational Administration and Management. 48 (3), 73-79.

[7] Jaiyeola, A. O., \& Atanda, A. I. (2003). Community participation in the provision of facilities in secondary schools in Nigeria. Paper presented on Effective Performance of Teachers in Secondary Schools held in Ondo State, Nigeria, $23^{\text {rd }}$ March.

[8] Kanak, H. B. (2015). Effectiveness of school based management committees and quality education in primary schools in Jema'a and Kaura local government areas of Kaduna state. Unpublished Master Dissertation, University of Jos.

[9] Ministry of Education, Jos (2007). Annual School Based Management Committee (SBMC) Report, Jos. Author. National Policy on Education (NPE, 2013).

[10] Ogundele, M. O. (2008). Funding, teachers' job satisfaction and students' academic performance in Kwara state primary secondary schools. Unpublished $\mathrm{PhD}$ thesis, University of Ilorin.

[11] Oyedeji, O. (2017). Budget on education. Retrieved from www.premiumkmesng.com., September $27^{\text {th }}$.

[12] Pam, O. L (2015). The effect of crises on quality primary education in Jos South LGA of Plateau State. Unpublished M. Ed. dissertation, University of Jos.

[13] Shaeffer, S. (2004). Collaborating for educational change. The roles of teachers, parents and the community in school improvement. Paris: UNESCO International Institute for Educational Planning

[14] Tekeu, R. F. (2011). Uganda broad community engagement critical to education success. The Independent, $8^{\text {th }}$ April.

[15] United Nations Educational Scientific and Cultural Organization (2017). How we plan to integrate 60,000 out of school children. The Nations Newspaper, May, p. 28. 